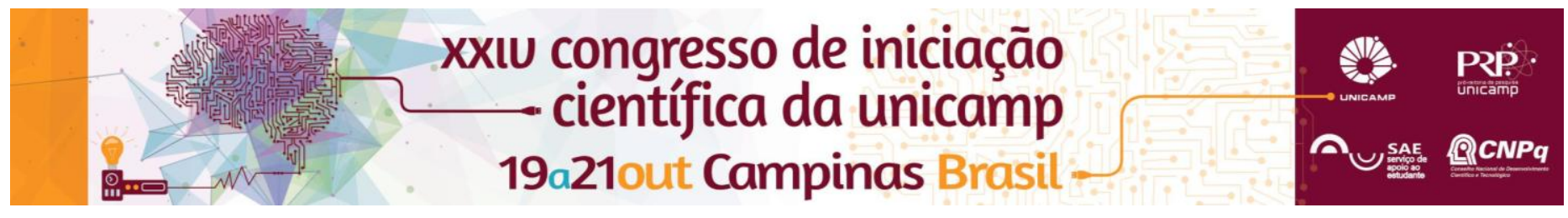

\title{
A Pequena Idade do Gelo: evidências históricas e geológicas de mudanças climáticas
}

\author{
Gabriel Bueno Fagundes de Freitas*, Celso Dal Ré Carneiro, Pedro Wagner Gonçalves
}

\begin{abstract}
Resumo
A pesquisa envolveu extenso aprendizado de diversos aspectos do intervalo conhecido como a Pequena Idade do Gelo. Foi feito estudo de métodos de datação, registros paleoclimáticos do Quaternário, oscilações do clima e variações ambientais, como por exemplo as grandes eras glaciais e mudanças eustáticas (variações do nível do mar). O objetivo principal deste trabalho entretanto foi compreender os processos que determinaram as variações climáticas específicas no período que se estende do século XVI ao século XIX, quando houve grande resfriamento no hemisfério norte, além de outros efeitos em escala mundial. A base de dados disponível é composta por vestígios preservados, que integram os registros histórico, geológico, biológico, geomorfológico, artístico, dentre outros. Com tais dados, os diversos autores estudados produziram diversos modelos paleoclimáticos para a época que, embora nem sempre convergentes entre si, colocam em evidência as tendências climáticas da época e algumas de suas implicações para as sociedades locais.
\end{abstract}

\section{Palavras-chave: Paleoclimatologia, Quaternário, Pequena Idade do Gelo.}

\section{Introdução}

O projeto visa o entendimento das mudanças climáticas, visto que o tema tem fundamental importância para a pesquisa científica no século XXI, principalmente com o atual alarde caracterizado como Aquecimento Global Antropogênico (AGA).

As causas naturais que determinam as variações climáticas são em geral pouco citadas ou simplesmente omitidas. Nesse contexto, a presente pesquisa focaliza o estudo das mudanças climáticas que ocorreram no Quaternário, na época conhecida como Pequena Idade do Gelo: entre os séculos XVI e XIX, várias regiões do globo apresentaram quedas na temperatura média, além de ter havido expansão de geleiras e outras mudanças ambientais. A pesquisa é essencialmente de natureza bibliográfica, buscando-se verificar interpretações sobre as mudanças a partir de livros, relatórios acessíveis e artigos publicados de investigações em diversas partes do globo, feitas por diferentes pesquisadores. O trabalho também objetiva construir conhecimento sobre os métodos de datação empregados em pesquisas em Ciências da Terra, além de outros dados que visam à construção de modelos paleoclimáticos.

\section{Resultados e Discussão}

A Pequena Idade do Gelo (Little Ice Age - LIA) foi o período mais recente durante o qual houve expansão ou manutenção das posições das geleiras, embora suas frentes tenham variado quanto à geometria de avanço. Não há clara tendência climática que concorde com o aumento das geleiras na LIA. Embora a época concentre de fato períodos de inverno mais longos e mais severos do que o Ótimo Climático Medieval e do que aqueles vivenciados pela humanidade no século $X X$, o frio e a seca de cada inverno não afetam significativamente o balanço de massa das geleiras.

Grandes avanços de geleiras ocorrem quando há uma combinação de primaveras e outonos muito frios junto de verões frios e úmidos. Uma variável muito importante que contribui para entender os LIA são os "anos sem verão", ocorrências muito bem documentadas no último milênio. A maior parte de tais fenômenos, senão todos, são ligados a erupções vulcânicas nos trópicos, que geram cobertura de cinzas vulcânicas em nível global. Contudo, em geral, as extensões de áreas afetadas pelos "anos DOI: 10.19146/pibic-2016-50735 sem verão" vão desde norte dos Alpes até a Bacia Parisiense a Oeste e a Fronteira Russa a Leste (Pfister \& Brázdil, 2006). O efeito de tais anos é contrabalanceado por verões quentes e secos, que causaram derretimento das geleiras. Tal época foi registrada por intermédio da datação e estudo de linhas de árvores e morenas (Luckman, 1993), informações geológicas de avanços e retrações de geleiras (Mann 2002 apud Grove 1988), além de fontes provindas de arquivos humanos, como dados documentais (Pfister \& Brázdil, 2006) e dados extraídos de obras de arte (Neuberger, 1970).

Mediante tais informações tornou-se possível elaborar modelos paleoclimáticos que ajudam no entendimento dos fenômenos de mudanças climáticas, além de seus impactos nas sociedades e na economia (Pfister \& Brázdil, 2006).

\section{Conclusões}

Os eventos de mudança climática resultam dos diversos fatores internos e externos que moldam os ciclos climáticos, começando pela quantidade de radiação solar, seguindo pelas variações na posição da Terra em relação ao Sol e, por fim, as taxas de reflexão, absorção, distribuição do calor e reemissão da radiação, sendo os últimos controlados pelas alterações na composição atmosférica, geometria da superfície terrestre e dos oceanos. No caso da Pequena Idade do Gelo, as variações climáticas estariam ligadas principalmente ao declínio da atividade solar e ao vulcanismo. O estudo é favorecido por dados de crescimento de árvores, de sedimentos de ambientes glaciais e fontes documentais e artísticas, que revelam a magnitude do impacto socioeconômico de tal evento e introduzem novos elementos para se contextualizar o que tem sido chamado de aquecimento global antropogênico.

'Grove JM. The Little Ice Age, 498 pp. Methuen, London. 1988.

${ }^{2}$ Luckman BH. Glacier fluctuation and tree-ring records for the last millennium in the Canadian Rockies. Quaternary Science Reviews. 1993 Jan 1;12(6):44150 .

${ }^{3}$ Mann ME. Little ice age. Encyclopedia of global environmental change. 2002; $1: 504-9$.

${ }^{4}$ Neuberger H. Climate in art. Weather. 1970 Feb 1;25(2):46-56.

"Pfister C., Brázdil R. Social vulnerability to climate in the" Little Ice Age": an example from Central Europe in the early 1770s. Climate of the Past. 2006 Oct 9;2(2):115-29. 